\title{
The Development of Blended Learning Model using Edmodo to Train Student Critical Thinking Skills on Impulse-Momentum Topic
}

\author{
Yus Rama Denny ${ }^{1, a)}$, Indri Sari Utami ${ }^{1, b)}$, Siti Rohanah ${ }^{1, \mathrm{c})}$, Dewi Muliyati ${ }^{2, \mathrm{~d})}$ \\ ${ }^{1}$ Physics Education Department, Universitas Sultan Ageng Tirtayasa, Serang, Indonesia \\ ${ }^{2}$ Physics Education Department, Universitas Negeri Jakarta, Jakarta Timur, Indonesia

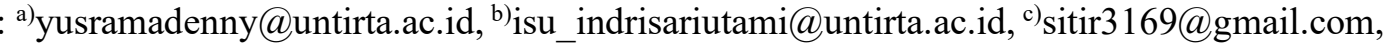 \\ d)dmuliyati@unj.ac.id
}

\begin{abstract}
This study determines the effect of developing blended learning models using Edmodo on students' critical thinking skills on impulse and momentum. The research method used in this study is ADDIE. The population in this study is class X MIA SMAN 4 Serang City. The sample of this study amounted to 31 students from class X MIA 2 as an experimental class using a blended learning model and 30 students from class X MIA 3 as a control class using a cooperative model. The test used in this study was seven indicators of critical thinking skills. These results indicate an increase in students' critical thinking skills after being given treatment that is by using a blended learning model. The $\mathrm{N}$-Gain value evidences a large increase in the experimental class that is 0.60 in the medium category and 0.23 in the low category in the control class. The average value of pretest and posttest is 5.27 and 9.77 in the control class, while in the experimental class is 5.65 and 16.61. These results show that there is an influence on the development of blended learning models for critical thinking skills on the momentum and impulses.
\end{abstract}

Keywords: blended learning model, critical thinking skills, edmodo, momentum and impulse

\section{INTRODUCTION}

During this time, students are accustomed to learning in the classroom led and controlled by the teacher (Deshpande 2021). Along with the development of technology, the use of technology has increased and has become a part of almost all sectors, including the education sector (Budi et al. 2019). Both teachers and students have easy access to technology, and teachers are facing a significant problem of seeking attention from students for a long time (Deshpande 2021). Teachers have been using technology extensively to create interest among students (Deshpande 2021).

The blended learning study is not new (Bouilheres 2020). The teachers have used innovative and creative ideas in their lesson planning and have tried to integrate traditional blend class teaching with technology. Blended learning is the development of e-learning models considered the most appropriate approach to moderate the learning needs of open society towards global change (Rimbawati \& Muchlas 2015). Positive findings regarding the blended learning approach have been documented over the past few decades (Bazelais 2018). According to the study by Babson Survey (2016), learning outcomes with a blended learning approach have more positive academic results than pure learning that only 
applies online systems. They argue that blended learning is superior, more effective, and hold much promise for teaching and learning (Allen \& Seaman 2015).

One technology that can be combined with blended learning is Edmodo (Hadjarati et al. 2020; (Murjainah et al. 2020). Edmodo learning can increase student participation actively and communicatively. They want to be active in the classroom and develop warm relationships with teachers through this learning management (Uzun 2015). Edmodo has advantages for users; in this case, the teacher can create classes virtually. Teachers can enter assignments, provide notes, and share learning material so students can learn from the website, get learning material, and do ability tests. This can be done using a laptop or smartphone. The use of Edmodo provides broader opportunities for students to take advantage of existing facilities so that the reference sources obtained are not limited (Murjainah 2020).

Blended learning using Edmodo can be applied in learning as an effort to improve students' soft skills (Murjainah et al. 2020) and cognitive abilities (Hadjarati et al. 2020). One of the cognitive abilities in question is critical thinking skills. Since childhood, basically, humans already have the tendency and ability to think critically. With an understanding of students' cognitive conditions and their high learning abilities, it can be concluded that education for critical thinking should be given to students since they are very young (Zamroni et al. 2020). But the fact is students' critical thinking skills are still considered low (Malik et al. 2018). Students' low critical thinking skills are shown by the difficulty of expressing their opinions because they are not confident with the answers mentioned. This feeling of insecurity arises because they do not understand physics matters, and finally, they respond to the matters on their basic knowledge. Learning success related to critical thinking skills can be seen from the domain of knowledge such as mental thinking activities such as predicting, analyzing, synthesizing, evaluating, reasoning, and so on (Tiruneh et al. 2017). Learning models that support the improvement of students' critical thinking skills need to be applied in classroom learning. Based on this, it is necessary to adjust the model and precise technology to enable students to think actively, ask questions, discuss, and conclude a problem. This supports blended learning as a learning model that facilitates students to train critical thinking skills (Hadisaputra 2020).

Critical thinking skills are essential things students must have, one of which is in learning the topic of mechanics. Mechanics is a field where students have various misconceptions and difficulties (Rosa et al. 2018). Momentum and impulse are the subtopics of mechanics and basic concepts in physics. However, many students are still having difficulty interpreting the concepts of momentum and impulses (Malik er al. 2018). Other research shows that students' ability to understand the concept of conservation momentum is still limited and cannot apply to different situations (Rosa et al. 2018). Students are weak in connecting physics equations with applications found in everyday life, for example, students misinterpret the momentum and kinetic energy of colliding objects because they have not linked the momentum and impulse theorem and energy business theorems in collision demonstrations (Faizah et al. 2019). The difficulty of students understanding the concepts in the material of momentum and impulses, among others, is in linking the relationship between momentum and impulses in problem-solving (Suryani 2013), understanding momentum as a vector quantity about conservation of momentum (Faizah et al. 2019). Students find it difficult to interpret the concepts of momentum and energy qualitatively as they apply to everyday physical problems. Student's difficulty in understanding physical concepts illustrates that students' conceptual understanding of momentum and impulses is in a low category. Though the concept of Momentum and Impulse becomes an important part of learning physics at various levels, this concept is learned from high schools to universities (Rosa et al. 2018). Based on this description, it is necessary to research to determine the blended learning model use in Indonesia to train the cognitive skills of students, especially critical thinking. The blended learning model development is carried out using the help of Edmodo technology.

\section{METHODS}

The research method used is the research and development method. The research and development model used is the ADDIE model. The steps in developing ADDIE are analyzed, design, develop, implement, and evaluate. The development of e-learning uses the ADDIE research and development model, which is explained in the following stages: 
1. Analyze stage; the researcher analyzed the needs of the research subjects, namely the students of SMAN 4 Kota Serang, taken as the sample. After a needs analysis is done, the data is then processed and gets results stating that high school students assume that the Momentum and Impulse is an abstract and challenging material to be studied and requires learning media that makes it easy for students.

2. Design stage, the design of the android application is carried out following the needs analysis data obtained, in this design following KD 3.10, namely applying the concept of momentum and impulse, and the conservation of momentum law in daily life.

3. Development stage, the researcher carried out the development stage of the application of momentum and impulse using the Edmodo application. Before entering the next stage, namely implementation, the validation test will be carried out first if it is accepted will proceed to the revision stage (evaluation) then to the final implementation, namely the field test.

4. Implementation stage or the field test, which is testing the final product in the form of an application to students of SMAN 4 Serang City, which is used as a sample subject. Researchers analyze product results and data on the use of the android application that was made.

\section{RESULT AND DISCUSSION}

\section{Edmodo Blended Learning}

The results of this development in the form of an android application in which there are teaching materials. The development of Edmodo-assisted blended learning models develops teaching materials in the form of Student Worksheets (LKPD). At the first meeting, students will be assigned to create Edmodo accounts, which can be downloaded in the play store or can be accessed on the web. To be able to use Edmodo as a learning medium, it is required to first register as a member, and members can choose to register as students, teachers, or parents. After students create an account, students will be given a class code, and they can join the class groups that have been created by the teacher. Before learning, students will be offered duty summarize, assigned by teachers on the Edmodo app, and collected in group classes that have been created. At each meeting, students will make a summary and collected in class groups. Students will work on assignments in groups results will be uploaded on the Edmodo application. At the end of student learning will be given an assignment in the form of questions related to the material that has been learned at the previous meeting. The learning is in accordance with the syntax of the blended learning model itself. The study was conducted with five meetings, including pretest and posttest.

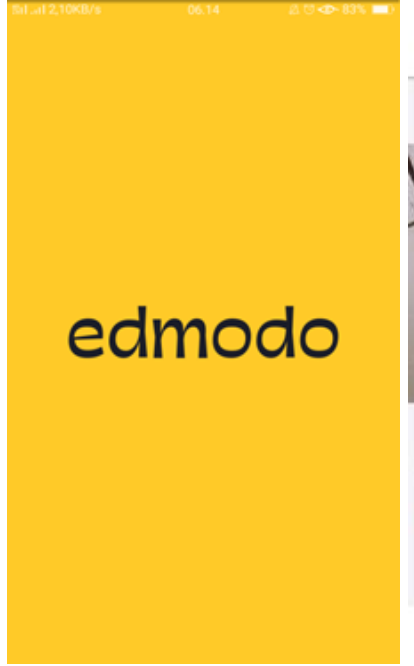

(a)

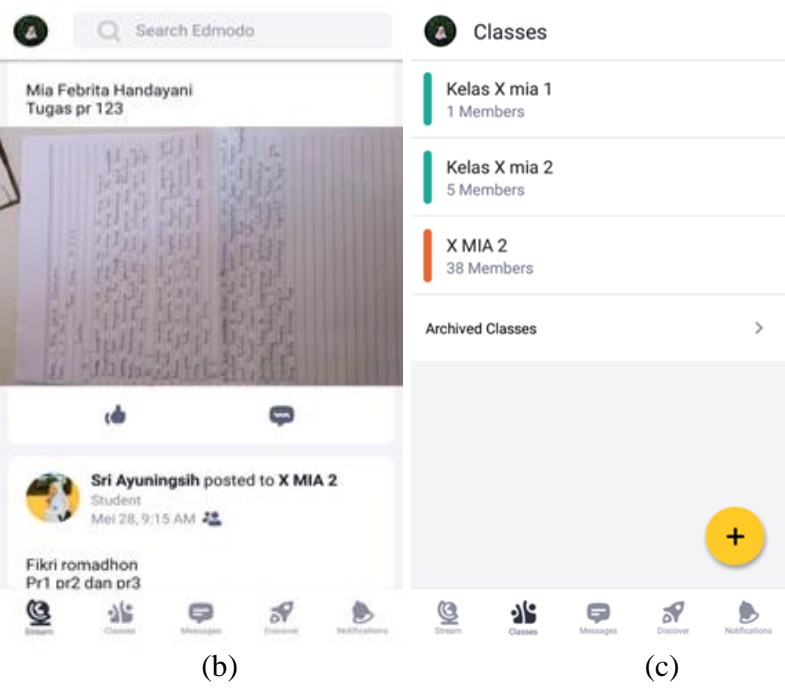

(b) (c)

FIGURE 1. (a) Screen display Edmodo; (b) Display menu; (c) Classes in Edmodo application 


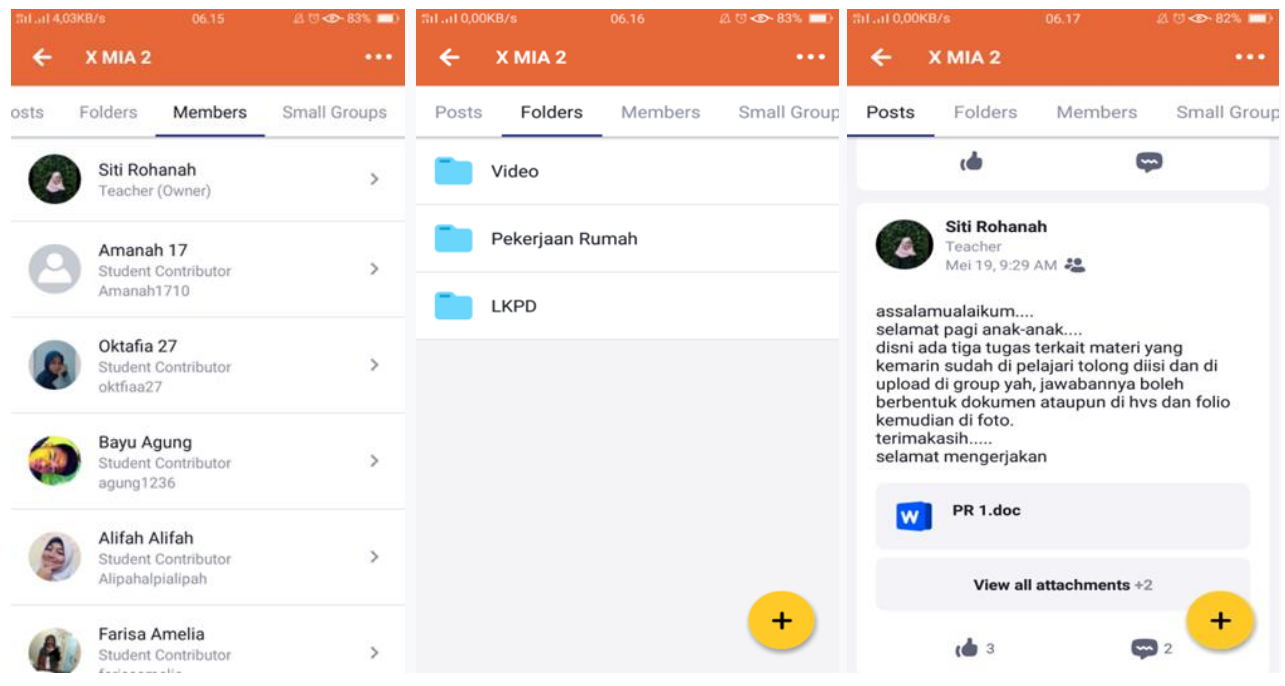

FIGURE 2. (a) Members of the class on Edmodo application; (b) Assignment folder; (c) Teacher assignments for students.

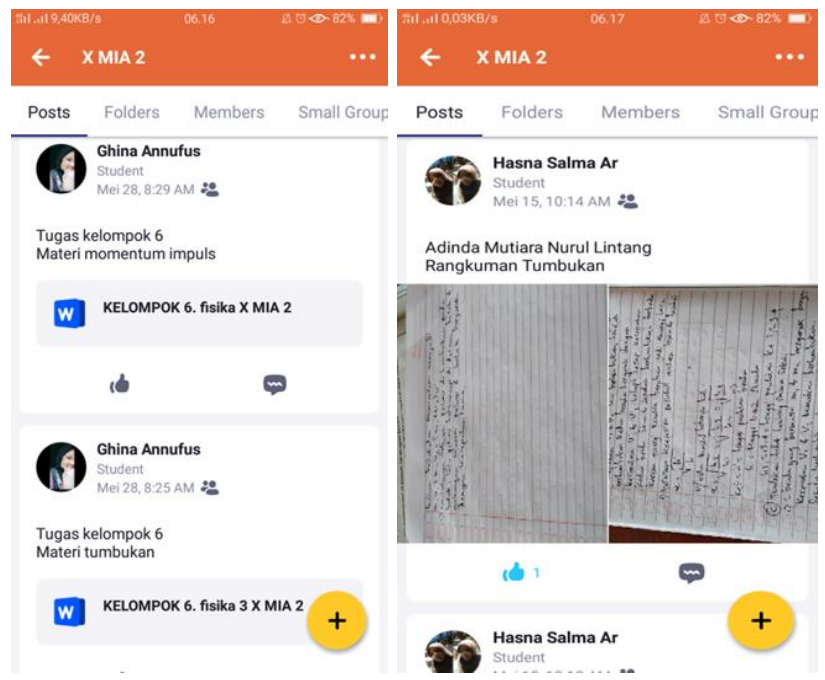

FIGURE 3. (a) Collection of group assignments; (b) Collection of individual tasks

\section{Critical Thinking Enhancement}

The results were obtained from the data in the form of critical thinking skills test scores of Momentum and Impulse students in the experimental class and the control class. Students' critical thinking skills are measured using the critical thinking skills test instrument. The instrument in this study had a high level of confidence, from the results of the reliability calculation obtained a value of 0.72. Based on the interpretation criteria, it can be said that the instrument has a high-reliability category. Descriptive analysis of learning outcomes in this study using the help of IBM software version 22. The average value of learning outcomes can be seen in TABLE 1 .

TABLE 1. Results of improvement in students' critical thinking

\begin{tabular}{lcccc}
\hline & \multicolumn{2}{c}{ Experiments } & \multicolumn{2}{c}{ Control } \\
\cline { 2 - 5 } & Pretest & Posttest & Pretest & Posttest \\
\hline Highest scores & 10 & 22 & 8 & 16 \\
Lowest scores & 2 & 9 & 1 & 6 \\
Mean & 5.65 & 16.61 & 5.27 & 9.77 \\
Standard deviation & 1.976 & 3.612 & 1.818 & 2.788 \\
\hline
\end{tabular}


Based on TABLE 1 it is found that there are differences in the pretest and posttest scores of the experimental and the control class. In the experimental class, the average pretest and posttest scores were 5.65 and 16.61, while in the control class, the average pretest and posttest scores only reached 5.27 and 9.77. The results of the critical thinking skills scores possessed by the experimental class showed higher numbers compared to the control class. The results of the calculation of research data obtained $\mathrm{N}$-gain score in the experimental class and control class can be seen in TABLE 2.

TABLE 2 Average N-Gain score results

\begin{tabular}{lll}
\hline & N-Gain Score & Category \\
\hline Experiments & 0.60 & Average \\
Control & 0.23 & Low \\
\hline
\end{tabular}

Based on TABLE 2 the results of the N-Gain score in the experimental class included in the average category with an $\mathrm{N}$-gain score of 0.60 . Whereas in the control class gets an $\mathrm{N}$-gain of 0.23 in the low category. It can be seen, the increase in students' critical thinking skills who are given blended learning treatment is higher than the increase in students' critical thinking skills that are not given blended learning treatment. A description of the average results of the pretest and posttest and N-Gain in the control and the experimental class can be seen in FIGURE 4.

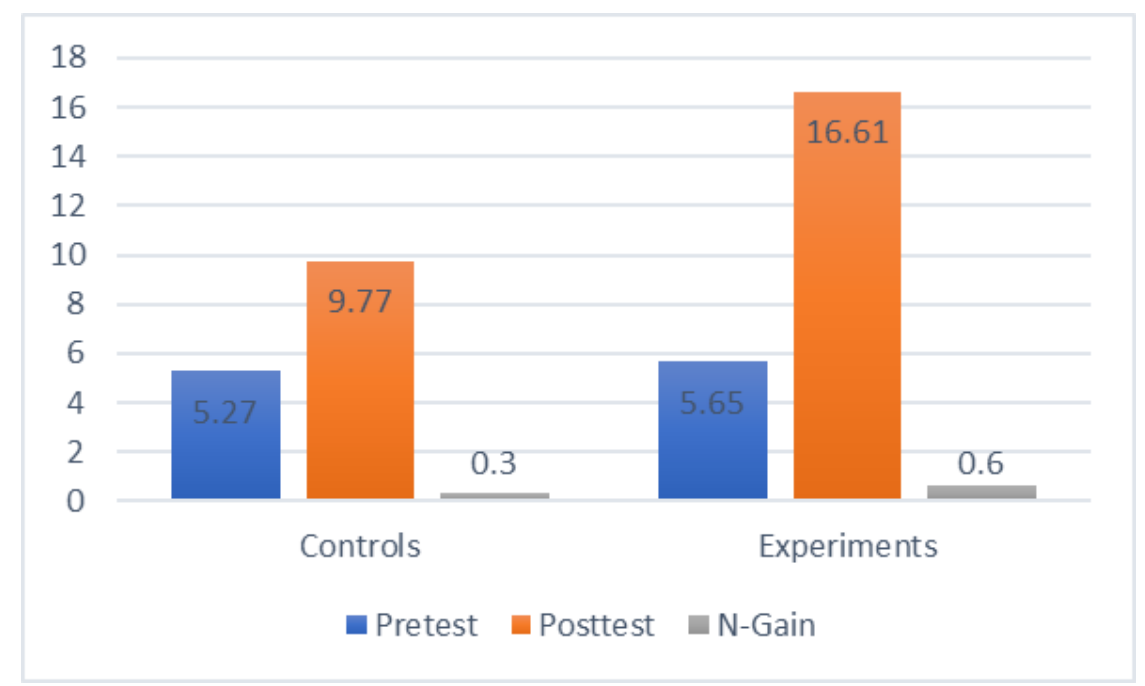

FIGURE 4. The average results of pretest and posttest and N-Gain in the control class and the experimental class

There are seven indicators of critical thinking skills assessment conducted in the control and experimental class. The results of testing the seven indicators are shown in TABLE 3.

TABLE 3. Results of testing the seven indicators of critical thinking skills

\begin{tabular}{|c|c|c|c|c|c|c|}
\hline \multirow[b]{2}{*}{ Indicators } & \multicolumn{3}{|c|}{ Experiments } & \multicolumn{3}{|l|}{ Control } \\
\hline & Pretest & Posttest & N-Gain & Pretest & Posttest & N-Gain \\
\hline 1. Focusing questions & 0.33 & 0.77 & 0.65 & 0.4 & 0.6 & 0.3 \\
\hline 2. Analyze the argument & 0.28 & 0.9 & 0.91 & 0.3 & 0.92 & 0.9 \\
\hline $\begin{array}{l}\text { 3. Observing and considering } \\
\text { the results of observations }\end{array}$ & 0.1 & 0.89 & 0.9 & 0.16 & 0.4 & 0.23 \\
\hline $\begin{array}{l}\text { 4. Create and review the } \\
\text { results of the values of } \\
\text { consideration }\end{array}$ & 0.5 & 1 & 1 & 0.4 & 0.5 & 0.2 \\
\hline $\begin{array}{l}\text { 5. Identifying terms and } \\
\text { considering definitions }\end{array}$ & 0.16 & 0.48 & 0.38 & 0.12 & 0.17 & 0.03 \\
\hline 6. Identify assumptions & 0.1 & 0.46 & 0.4 & 0.1 & 0.2 & 0.1 \\
\hline 7. Determine the action. & 0.34 & 0.82 & 0.72 & 0.3 & 0.53 & 0.3 \\
\hline
\end{tabular}


The indicator focusing questions, students are required to analyze a question with the problems presented, such as a car crashing into a tree from the event students must be able to explain the event using the theory of impulse and momentum. In the experimental class, there are stages where students must summarize learning material before the meeting at school, so students know the general picture of the material to be taught. Whereas in the control class, students only discuss groups, so they are less able to stimulate students to reach indicators focusing questions.

The indicators analyzing the argument results of the N-Gain value is not much different, because in the class using the blended learning model does not present a problem during the learning process. Observing and considering indicators of the results of observations show an increased score of critical thinking skills in the experimental class is higher than the control class because researchers have prepared to learn media in the form of microscopic animated videos downloaded by students before learning in class. So students can observe and consider the results of observations to answer the questions given by the teacher. Whereas in the control class, students only discuss groups and use teaching materials in the form of textbooks and worksheets.

The Create and review indicator, the results of the values of consideration the experimental class, get a greater $n$-gain value than the control class. This is because, in the experimental class, there are stages of practice/trial (let me) in the syntax of blended learning where students are required to find learning resources online and offline. Students are required to look for as many learning resources, and this is intended so that students' knowledge/insight is broad. When students have comprehensive insights, students are expected to be able to analyze and answer questions correctly. Whereas in the learning control class by means of discussions with groups and teaching materials in the form of textbooks and worksheets.

The indicators Identifying terms and considering definitions indicate the success of learning in the experimental class compared to the control class. Nevertheless, the value obtained is very little difference because when learning using the blended learning model, researchers do not present problems and learning resources. The identifying assumptions indicator, the value of N-Gain in the experimental class is greater than the control class. This is because, in the experimental class, the blended learning model is used in that model, there is a "coach me" stage. At the "coach me" stage or peer tutors, students are required to assume and determine whether or not the assumptions they make, so that they can identify assumptions. Whereas in the control class students are less able to identify assumptions, because students in the control class only learn by ordinary discussion.

The determine action indicator based on existing problems. The "coach me" stage also affects improving this indicator. Because with the peer tutors, students can more easily express their opinions, it is easier to understand the material delivered by their friends, because the language used by their friends is easier to understand. Whereas in the control class, there are no peer tutoring stages.

Based on the result and discussion about the data in TABLE 3, in general, it can be concluded that students' critical thinking skills in both classes increased after being given different treatments. The experimental class was treated using a blended learning model while learning in the control class did not use the blended learning model. The results obtained are the same as previous studies which, have proven that the application of the blended learning model can improve students' critical thinking skills (Fariska \& Erman 2017; Arohmatul \& Sumarni 2019).

\section{CONCLUSION}

Based on the results and discussion, it can be concluded that the development of the blended learning model using Edmodo can influence students' critical thinking skills on the topic of momentum and impulse in SMAN 4 Serang City. This conclusion was obtained by looking at the increase in the $\mathrm{N}$-Gain value of the seven indicators of critical thinking skills. 


\section{REFERENCES}

Allen, IE \& Seaman, J 2015, Grade level: Tracking online education in the United States, Babson Park, MA: Babson Survey Research Group.

Allen, IE, Seaman, J, Poulin, R, \& Taylor Straut, T 2016, Online report card-Tracking online education in U.S. higher education, Babson Park, MA: Babson Survey Research Group.

Arohmatul, K \& Sumarni, W 2019, 'The Effectiveness Of Blended Problem-Based Learning For Enhancing Cognitive And Learning Outcomes Of Students' Critical Thinking Skills On Redox Materials', Jurnal Pengajaran MIPA, vol. 24, no. 1.

Bazelais, P \& Doleck, T 2018, 'Investigating the impact of blended learning on academic performance in a first semester college physics course', Journal of Computers in Education, vol. 5, pp. 67-94.

Bouilheres, F, et al 2020, 'Defining student learning experience through blended learning', Educ Inf Technol, vol. 25, pp. 3049-69.

Budi, AS, Muliyati, D, Ambarwulan, D, \& Bakri, F 2019, 'The development of ICT-based learning curriculum for pre-service physics teacher', J. Phys.: Conf. Ser., vol. 1318, p. 012137.

Deshpande, S \& Shesh, A 2021, 'Blended Learning and Analysis of Factors Affecting the Use of ICT in Education', Next Generation Information Processing System, pp. 311-32.

Faizah, WAA, Suparmi, S, \& Aminah, NS 2019, 'Analysis of Student Concepts Understanding in Solving Scientific Literacy on the Topic of Momentum and Impulse', J. Phys.: Conf. Ser., vol. 1155, p. 012025.

Fariska, R \& Erman, 2017, 'Blended Learning Untuk Meningkatkan Level Kemampuan Berpikir Kritis', Pensa E-Jurnal: Pendidikan Sains, vol. 5, no 2, pp. 60-6.

Hadisaputra, S, Ihsan, MS, Gunawan, G, \& Ramdani, A 2020, 'The development of chemistry learning devices based blended learning model to promote students' critical thinking skills', J. Phys.: Conf. Ser., vol. 1521, p. 042083.

Hadjarati, YA, Arota, AS, Mursalin, M, Odja, AH 2020, 'Effectiveness of edmodo to improve senior high school students' creative thinking skills in momentum and impulse topics', J. Phys.: Conf. Ser., vol. 1521, p. 022065.

Malik, A, Vitriani, V, \& Chusni, MM 2018, 'Improving Students' Critical-Thinking Skills Through Student Facilitator and Explaining Model in Momentum and Impulse Topic', JPPPF (Jurnal Penelitian \& Pengembangan Pendidikan Fisika), vol. 4, no. 2, pp. 55-64.

Murjainah, et al. 2020, 'Improvement of students' soft skills (honesty and motivation) using edmodo by Blended Learning Method', IOP Conf. Ser.: Earth Environ. Sci., vol. 485, p. 012117.

Rimbawati, N \& Muchlas 2015, 'Pengembangan Model Pembelajaran Adaptive Blended Learning untuk Berbagai Jenis Gaya Belajar Siswa Menengah Atas pada Pokok Bahasan Listrik Statis', JPPPF (Jurnal Penelitian \& Pengembangan Pendidikan Fisika), vol. 1, no. 2, pp. 1-6.

Rosa, GC, Cari, C, Aminah, NS, \& Handhika, J 2018, 'Students' understanding level and scientific literacy competencies related to momentum and impulse', J. Phys.: Conf. Ser., vol. 1097, p. 012019.

Suryani, I 2013, 'Keterampilan Berpikir Kritis Siswa dalam Menyelesaikan Soal Fisika tentang Impuls dan Momentum', Jurnal Pendidikan Fisika, vol. 4, no. 2, pp. 1-8.

Tiruneh, DT, De Cock, M, Weldeslassie, AG, Elen, J, \& Janssen, R 2017, 'Measuring Critical Thinking in Physics: Development and Validation of A Critical Thinking Test in Electricity and Magnetism', Int $J$ of Sci and Math Educ, vol. 15, no.4, pp. 663-82.

Uzun, E 2015, 'Students' Attitude Towards Edmodo as a Supplementary Tool for Higher Education', Participatory Educational Research Special Issue, pp.78-83. 
Zamroni, E, Muslihati, Lasan, BB, \& Hidayah, N 2020, 'Blended Learning based on Problem Based Learning to Improve Critical Thinking Ability of Prospective Counselors', J. Phys.: Conf. Ser., vol. 1539, p. 012039. 